一一論 文—

（日本化学会誌，1993，（4)，p.349～354）

(C) 1993 The Chemical Society of Japan

\title{
多变量解析法による複数のフラグメントイオン強度からの ニトラゼパムとジアゼパムの定量分析
}

（1992 年 9 月 30 日受理）

\author{
佐 藤 元 泰・三 井 利 幸* $^{*}$
}

ニトラゼパムおよびジアゼパムをガスクロマトグラフ質量分析計（GC/MS）で測定後，得られた複 数のフラグメントイオンのイオン強度を用いて，多变量解析法によりそれぞれの定量を行った。定量計 算に使用するニトラゼパム，ジアゼパムおよび内部整準物質として用いたドトリアコンタン $\left(n-\mathrm{C}_{32} \mathrm{H}_{86}\right)$ の複数のフラグメントイオンは, 数量化理論第 $\mathrm{N}$ 類を用いて抽出した。次に, 抽出された複数のフラク メントイオンのイオン強度を基にして，クラスター分析，偏差值からのクラスター分析拉よび主成分分 析を行い，米知試料がどの既知試料に最も類似しているかを明らかにした。さらに，主成分分析から得 られる主成分得点と固有值を用いて，正確に未知試料の濃度を決定した。計算されたニトラゼパムおよ びジアゼパムの濃度は，理論値とほぼ一致し，精度の高い定量が可能となった。

\section{1 緒 曹}

GC/MS は, 未知成分, 特に多成分系の試料の同定特よび定貫 に用いられている。したがって，䇅判化学の分野においても，医

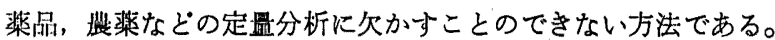
定量分析には，塤量クロマトグラフィー（MC）あるいは避択 イオン検出 (SIM) などの分析手法が用いられ，一般に定量分析 操作では，まず複数の湴度既知の陚料 (既知試料) を测定し，そ れらの测定值と浱度から最小二乘法で㭘量線を作成後，この検量 線に湴度未知の試料（未知陚料）の湘定值を代入し定冨を行って いる。しかしこの方法では，未知試料の测定值と既知陚料（愉哲 線）の测定值間の相関関係はまったく考感されていない。そのた めに，未知陚料の测定值のばらつきがそのまま定貫結果に影響を 与えることがある。

そこで，目的物質就よび内部標淮物質から得られるそれぞれの

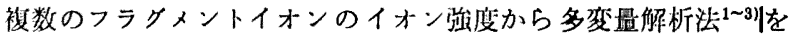
用いて既知試料と未知試料の测定値間の相関関係を考感しながら 定䕎与る方法を众討した。このように複数のフラグメントイオン を用い，既知試料と米知試料の测定值間の相闺関係を考鱀するこ とによりそそれらのイオン強度間のばらつきが互いに相殺され， より信頼性の高い定量が可能となる。既に著者らは，多变量解析 法を再現性の悪いX線回折法の定置分析 ${ }^{4), 5)}$ に応用し，渾足のい

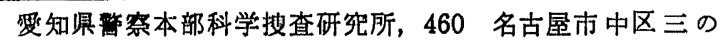
丸 2-1-1

1）奥野忠一，久米 均，芳賀饭郎，吉沢 正，“多变量解析 法”，日科技速 (1971)，pp. 163 175，pp. 362 370.

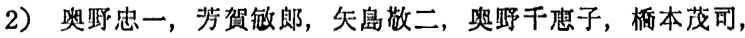
古河陽子，“続多变解解析法”，日科技連 (1976)，pp. 116 $\sim 131$, pp. 183 195, pp. 215 216.

3）田中 豊, 脇本和昌, “多变週解析法”, 現代数学社 (1983), pp. $171 \sim 176$

4）三井利幸，奥山修可，藤村義和，日化，1991，979.
く定量結果を得ている。さらに，多变盟解析法による定量は，测 定により得られたフラグメントイオンから分析者の主観によって 1から数個のフラグメントイオンを抽出することをせず, 客覞的 に抽出したすべてのフラグメントイオンの強度を同一の重みにし て結論を孟きたしている。

多变量解析法による定悬は，まず数圔化理論第 $\mathrm{N}$ 類を用いて， 未知試料を含めた定量計算に使用し得る互いに相関性の高い複数 のフラグメントイオンを抽出し，相関性の低いものは計算から除 外する。したがって，一定の規則に従わないフラグントイオン は,ここで除外される。次に, クラスター分析, 偏差値からのク ラスター分析を行い, 既知試料と未知陚料のデータ間の類似性を 求め，未知試料がどの既知試料に最も近似しているかを明らかに する。さらに, 主成分分析から得られる主成分得点扰よび，その 主成分得点が既知陚料と未知試料を含む試料全体の内容をどの程 度説明しているかを示す固有值を用いる方法で，目的物質の定量 を行った。

今回は，襍数の催呡薬を誤使用した結果得られる試料から，迅 速に精度よく分析することを目的として，GC/MS による複数の 催呡薬の同時定盢について众討した。众討した複数の催呡薬とし ては，比校的よく愦使用されているニトラゼバムとジアゼパムの 混合物を用いた。

\section{2 実験}

\section{1 践 菲}

ニトラゼパム拉よびジアゼパムは，三共製薬からの供与品を， ドトリアコンタン $\left(n-\mathrm{C}_{32} \mathrm{H}_{66}\right)$ は，東京化成製特級試薬をそのま ま使用した。

5) T. Mitsui, S. Okuyama, Y. Fujimura, Anal. Sci., 7, 941(1991) 
Table 1 Operating conditions of instrument
Column

Injector temp

Separator temp

Inlet temp

Chamber temp

Eelctron accelerating voltage

Ionization current

Carrier gas
Column temp

\section{2 装 置}

GC/MS は，日本電子製 DA 1000 のデータ処理装置付きの JMS-DX 300 を使用した。分析条件は，表 1 に示すとおりであ る。

多変量解析法による計算には, NECPC-9801 RX パーソナルコ ンピューターを使用した。言語は BASIC である。

\section{3 結 果と考察}

\section{1 データファイルの作成}

ニトラゼパムおよびジアゼパムは, 表 2 に示すようになるよう に，またドトリアコンタンは, $50.5 \mu \mathrm{g} / \mathrm{ml}$ になるようにクロロホ ルムに溶解し，その溶液 $3 \mu l$ を用いて GC/MS で分析を行っ た。試料 No. 1 から 5 を既知試料，No. 6 から 10 を末知試料と した。ニトラゼパム，ジアゼパム拉よびドトリアコンタンの各全 イオンクロマトグラム上の頂点に相当する走查番号と, さらにそ の前後の走查番号の質量スペクトルを求め, すべてのフラグン トイオンのイオン強度を測定した。次に，この三つの走査番号に おけるイオン強度をフラグメントイオンごとに加算し，得られた イオン強度（合計イオン強度）を用いて，多変量解析法による定 量分析の計算に使用可能なフラクメントイオンの組み合わせを数 量化理論第 N類により抽出した。その結果, 表 3 に示したよう に, ニトラゼパムから 11 個, ジアゼパムから 9 個, ドトリアコ ンタンから 13 個のフラグメントイオンの組み合わせ（イオンク ロマトクラム上の頂点に相当するフラグメントイオン，カテゴリ 一) が得られた。次に, ドトリアコンタンの各フラグンンイオ ンの合計イオン強度に対する, ニトラゼバム扰よびジアゼパムの 個々のフラグメントイオンの合計イオン強度を, 同一試料中のド トリアコンタンの個々の合計イオン強度で順次割り, ニトラビパ ムの 11 個, ジフゼパムの 9 個の各フラクメントイオンごとに得 られた値を合計した。すなわち，1試料につき，ニトラゼパムか ら 11 個，ジアゼパムから9個のカテゴリーが得られる。ニトラ ゼパの未知試料 No. 6 を例として, 補遣に計算方法の詳細を示
Table 3 Combinations of fragment ions subtracted from nitrazepam, diazepam and dotriacontane

(1) Nitrazepam

\begin{tabular}{crcc}
\hline $\begin{array}{c}\text { Category } \\
\text { No. }\end{array}$ & $m / z$ & $\begin{array}{c}\text { Category } \\
\text { No. }\end{array}$ & $m / z$ \\
\hline 1 & 77 & 7 & 253 \\
2 & 205 & 8 & 254 \\
3 & 206 & 9 & 264 \\
4 & 207 & 10 & 280 \\
5 & 234 & 11 & 281 \\
6 & 252 & &
\end{tabular}

(2) Diazepam

\begin{tabular}{cccc}
\hline $\begin{array}{c}\text { Category } \\
\text { No. }\end{array}$ & $m / z$ & $\begin{array}{c}\text { Category } \\
\text { No. }\end{array}$ & $m / z$ \\
\hline 1 & 221 & 6 & 283 \\
2 & 255 & 7 & 284 \\
3 & 256 & 8 & 285 \\
4 & 257 & 9 & 286 \\
5 & 258 & &
\end{tabular}

(3) Dotriacontane

\begin{tabular}{crcc}
$\begin{array}{c}\text { Category } \\
\text { No. }\end{array}$ & $m / z$ & $\begin{array}{c}\text { Category } \\
\text { No. }\end{array}$ & $m / z$ \\
\hline 1 & 85 & 8 & 183 \\
2 & 99 & 9 & 197 \\
3 & 113 & 10 & 211 \\
4 & 127 & 11 & 225 \\
5 & 141 & 12 & 239 \\
6 & 155 & 13 & 450 \\
7 & 169 & &
\end{tabular}

す。このよらにして計算した結果, 表 4 に示すような各カテゴリ 一に対する数值が得られた。多変量解析法の計算には, 五つの既 知試料（従来からの定量方法で検量線に相当するもの）に一つの 未知試料を加光た六つの試料を使用した。すなわち、ニトラゼパ ムについては $6 \times 11$ 行列, ジアゼパムについては $6 \times 9$ 行列で計 算を行った。

\section{2 クラスター分析}

表 4 に示したデータファイルを用いてクラスター分析を行った ところ, 表 5 に示すような結果が得られた。表 5 内の最小ューク リッド距離 (MIED) は，ある未知試料から最も近い既知試料ま でのユークリッド距離である。たとえば, ニトラゼパムの未知試 料 No. 6 の MIED は 2133 であり, 既知試料 No. 2 と最も類似 性が高い。一方, 最大ユークリッド距離 (MAED) は, 未知試料 を含む試料内で，最も遠く離れた試料間のユークリッド距離を示

Table 2 Concentrations of nitrazepam and diazepam in sample solutions

\begin{tabular}{crrrrrr} 
& \multicolumn{2}{c}{ Concentration $(\mu \mathrm{g} / \mathrm{m} l)$} & & \multicolumn{2}{c}{ Concentration $(\mu \mathrm{g} / \mathrm{m} l)$} \\
\cline { 2 - 3 } \cline { 5 - 6 } Sample No. & Nitrazepam & Diazepam & No. & Nitrazepam & Diazepam \\
\hline 1 & 40.3 & 160.3 & 6 & 80.6 & 144.3 \\
2 & 120.9 & 128.3 & 7 & 161.2 & 112.2 \\
3 & 201.5 & 96.2 & 8 & 241.8 & 80.2 \\
4 & 282.1 & 64.1 & 9 & 282.1 & 64.1 \\
5 & 362.7 & 32.1 & 10 & 322.4 & 48.1
\end{tabular}


Table 4 Filed data of nitrazepam and diazepam used for multivariate analysis

(1) Nitrazepam

\begin{tabular}{|c|c|c|c|c|c|c|c|c|c|c|c|}
\hline Sample No. & & & & & & tegory $\mathrm{N}$ & & & & & \\
\hline & 1 & 2 & 3 & 4 & 5 & 6 & 7 & 8 & 9 & 10 & 11 \\
\hline 1 & 6.238 & 5.964 & 9.593 & 4. 265 & 8. 947 & 8. 102 & 13.940 & 6.995 & 4.730 & 13.214 & 12.481 \\
\hline 2 & 22.112 & 22.493 & 39.383 & 15.876 & 38.628 & 32.494 & 59.196 & 28.471 & 18. 858 & 57.134 & 52.289 \\
\hline 3 & 46. 272 & 44.367 & 77.320 & 33. 245 & 74.859 & 65.279 & 115.500 & 55.508 & 39.448 & 117.699 & 103.875 \\
\hline 4 & 65.133 & 66.440 & 116. 455 & 48. 487 & 113. 224 & 97.940 & 179.246 & 84.059 & 58.865 & 182.174 & 160.958 \\
\hline 5 & 109. 918 & 100.796 & 175.180 & 72.391 & 167.344 & 147.181 & 256.610 & 124.971 & 87.870 & 266.153 & 234. 539 \\
\hline 6 & 14.497 & 14.226 & 24.982 & 10.676 & 22.947 & 19.993 & 37.245 & 17.772 & 12.078 & 37.465 & 33.834 \\
\hline 7 & 35.969 & 34.133 & 58. 394 & 24.875 & 56.740 & 48. 888 & 88.174 & 42.824 & 30.579 & 88.293 & 78.934 \\
\hline 8 & 59.251 & 56.157 & 99.581 & 42.133 & 94.999 & 82.610 & 149.574 & 71.729 & 49.783 & 152.084 & 134. 862 \\
\hline 9 & 66.996 & 65.816 & 118. 226 & 49.444 & 115. 229 & 96.927 & 181.837 & 83.791 & 59. 595 & 180.499 & 158. 547 \\
\hline 10 & 93.678 & 86.304 & 149. 664 & 61.041 & 141.141 & 121.437 & 225.246 & 106.609 & 72.738 & 224.105 & 195.914 \\
\hline
\end{tabular}

(2) Diazepam

\begin{tabular}{|c|c|c|c|c|c|c|c|c|c|}
\hline Sample No. & & & & Cate & y No. ${ }^{b l}$ & & & & \\
\hline & 1 & 2 & 3 & 4 & 5 & 6 & 7 & 8 & 9 \\
\hline 1 & 69.423 & 122.216 & 341.213 & 132.381 & 121.278 & 286.777 & 276.877 & 140.274 & 92.568 \\
\hline 2 & 52.377 & 80.652 & 254.389 & 97.634 & 89.681 & 212.924 & 206.947 & 102.938 & 67.665 \\
\hline 3 & 36.761 & 63.943 & 178.325 & 68.324 & 61.639 & 148.032 & 142.026 & 71.227 & 45.810 \\
\hline 4 & 25.101 & 29. 995 & 117.227 & 45.537 & 34.967 & 98.038 & 94.513 & 47.739 & 30.921 \\
\hline 5 & 12.503 & 23. 592 & 60.773 & 24.550 & 21.842 & 51.635 & 48.882 & 24.618 & 16.022 \\
\hline 6 & 61.478 & 107.185 & 301.744 & 117.768 & 107.781 & 256.610 & 244.350 & 123.938 & 83.148 \\
\hline 7 & 44.187 & 76.797 & 217.114 & 84.257 & 77.468 & 182.515 & 174.272 & 87.767 & 57.608 \\
\hline 8 & 29.284 & 53.715 & 145.980 & 56.315 & 51.048 & 122.096 & 114.623 & 58.181 & 38. 498 \\
\hline 9 & 23.089 & 42.272 & 113.968 & 43.993 & 40.094 & 94.924 & 90.966 & 45.642 & 30.104 \\
\hline 10 & 16.064 & 30.141 & 77.312 & 32.274 & 29.195 & 65.270 & 62.410 & 32.123 & 20.260 \\
\hline
\end{tabular}

a) The category number corresponds to the fragment ions of nitrazepam in Table 3.

$b$ ) The category number corresponds to the fragment ions of diazepam in Table 3.

Sample No.1 5: Known samples, Sample No.6〜10: Unknown samples.

Table 5 Results of nitrazepam and diazepam from multivariate analysis

(1) Nitrazepam

\begin{tabular}{rrrccc}
\hline Sample & \multicolumn{2}{c}{ Cluster analysis } & $\begin{array}{c}\text { Cluster analysis } \\
\text { from deviation } \\
\text { NKS }^{c}\end{array}$ & $\begin{array}{c}\text { Principal component } \\
\text { analysis } \\
\text { NKS }^{c)}\end{array}$ \\
\cline { 2 - 6 } & MIED $^{a)}$ & MAED $^{b)}$ & NKS $^{(1)}$ & 2 & 2 \\
7 & 2133 & 293692 & 2 & 3 & 3 \\
8 & 3709 & 293692 & 3 & 4 & 4 \\
9 & 3734 & 293692 & 4 & 4 & 4 \\
10 & 29 & 293692 & 4 & 5 & 5
\end{tabular}

Minimum and maximum Euclidian distance calculated from only known samples are 9246 and 293692, respectively.

(2) Diazepam

\begin{tabular}{cccccc}
\hline & \multicolumn{2}{c}{ Cluster analysis } & $\begin{array}{c}\text { Cluster analysis } \\
\text { from deviation } \\
\text { NKS }^{c}\end{array}$ & $\begin{array}{c}\text { Principal component } \\
\text { analysis } \\
\text { NKS }^{c}\end{array}$ \\
\cline { 2 - 6 } MIED $^{a)}$ & MAED $^{b)}$ & NKS $^{c}$ & & 1 \\
6 & 4569 & 239187 & 1 & 1 & 2 \\
8 & 4296 & 239187 & 2 & 2 & 3 \\
9 & 2941 & 239187 & 4 & 3 & 4 \\
10 & 220 & 239187 & 4 & 4 & 5
\end{tabular}

Minimum and maximum Euclidean distance calculated from only known samples are 8880 and 239187, respectively.

a) Minimum Euclidean distance. b) Maximum Euclidean distance.

c) Nearest known sample number. 
している。もし、この MAED が, 既知試料のみから計算された MAED と同一であるならば，その未知試料は，既知試料のクラ スター（集合）内に存在する。すなわち未知試料の濃度は, 既知 試料の濃度範囲内に存在していることを示している。これは従来 から行われている検量線による定量法でいえば，検量線の範囲内 にあることになる。表 5 に示した各未知試料の MAED は, 既知 試料のみの MAED と一致することから，今回計算した各未知試 料は，すべて既知試料の濃度範用内に存在することが明らかとな った。

\section{3 偏差値からのクラスター分析}

表 4 に示したデータファイルのカテゴリー間の数值に大きな差 異がある時, 分析結果は, より大きな数值を示すカテゴりーに, より大きな影響を受けると考えられる。そこで，カテゴリ一間の 重みを均一にすることを目的として, 表 4 に示したデータファイ ルの内, 五つの既知試料に一つの未知試料を加えた $6 \times 11$ 行列, $6 \times 9$ 行列の各行列をカテゴリーごとに偏差值に直し, カテゴリ 一間の重みを均一にしてクラスター分析を行った。その結果, 表 5 に示したよらに, ジアゼパムの未知試料 No. 8 以外は, クラス ター分析と同一の結果が得られ, 今回は, 各カテゴリ一間の重み に大きな差はないものと判断された。

\section{4 主成分分析}

表 4 に示したデータファイルの内，五つの既知試料に一つの未 知試料を加えた $6 \times 11$ 行列, $6 \times 9$ 行列のカテゴリ一間の相関関 係を求め，ついでこの相関関係から主成分分析を行った。さら に, 得られた主成分得点を用いてウォード法によりクラスター分 析を行い, 結果をデンドログラムで表示した。デンドログラム は, 結ばれた試料間のユークリッド距離が小さいものほど, 試料 間の類似性の程度が高いことを示す。図 1 に, ニトラゼパムの未 知試料 No. 6 の主成分分析結果のデンドログラムを示した。この 結果では, 未知試料 No.6 は, 既知試料 No. 2 と最も類似珄が高 いことがわかる。他の未知試料についても同様に検討したとこ ろ, 表 5 に示すよらな結果が得られた。

\section{5 主成分得点からの未知試料濃度の決定}

上記の方法で, 未知試料中の=トラゼパムおよびジアビパムの 濃度の推定が可能となった。次に, さらに正確な濃度の測定を行

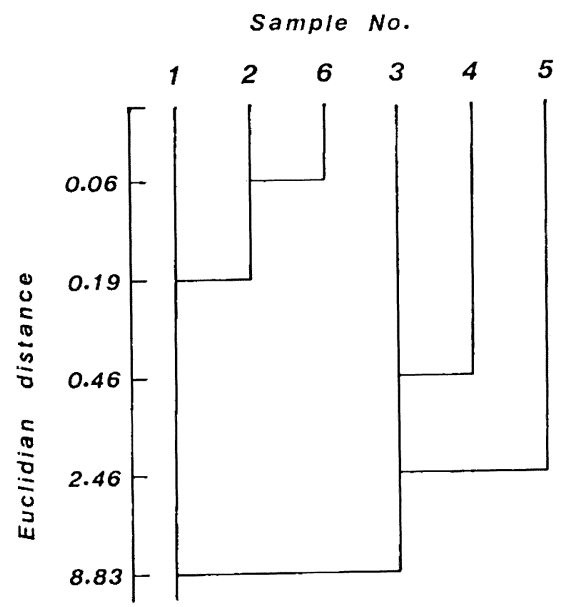

Fig. 1 Dendrogram of unknown sample No. 6 for nitrazepam
らために, 各試料から得られた主成分得点と固有值を用いて, 未 知試料中のニトラゼパム拈よびジアゼパムの定量を行った。主成 分分析で定量する目的は, 従来の検量線を用いる方法とは異な り，情報として得られる 1 試料からの複数の測定值すべてを定量 分析のための対象とすることと, 定量時に, 未知試料の測定值と 既知試料の測定值間の相関関係を見ていることである。すなわ ち, 本方法は, 既知試料の測定值間のみの相関関係から検量線を 作成した後，未知試料の測定値を，あらかじめ作成してある 1 本 の検量線に代入して定量するという従来法とは基本的に異なる。

定量計算には，1.000 以上の固有値から得られる主成分得点の みを用い，第 1 主成分得点を除くものについては，固有値を用い て主成分得点の補正を行う。1.000 以上の固有値を持つ主成分得 点のみで定量分析を行ったのは, 固有値 1.000 以上で定量分析に 用いた湘定值全体の内容（主成分分析に用いた行列）の約 $98 \%$ 以上が説明できることと，各試料に対する主成分得点の数が多い と計算に長時間を必要とするためである。

今回は, 1.000 以上の固有值を示す主成分が一つであり，第 1 主成分以外の各主成分は, 表 4 に示した測定值の行列に対する寄 与率が極めて小さいことから，第 1 主成分に対する第 1 主成分得 点のみで定量した。ニトラゼパムの未知試料 No. 6 を例として, 補遺に計算方法を示す。未知試料 No. 6 から No.10 についての 定量結果 (計算結果) は, 表 6 に示すとおりであり，理論值との 差は平均して, ニトラゼパムで $1.8 \%$ ，ジアゼパムで $2.9 \%$ であ った。またニトラゼパム $201.5 \mu \mathrm{g} / \mathrm{m} l$ とジアゼパム $96.2 \mu \mathrm{g} / \mathrm{m} l$ を用いて本方法と従来法との再現性を検討した。従来法は, 分子

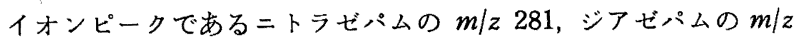
286 およびドトリアコンタンの $m / z 450$ のイオン強度を用いて最 小二乗法で行った。その結果, 本方法による相対標準偏差は, = トラゼパムで $0.9 \%(n=10)$, ジアゼパムで $0.3 \%(n=10)$ であ り, 従来法では, ニトラゼパムで $3.8 \%(n=10)$, ジアゼパムで $3.5 \%(n=10)$ であった。このことから，本方法は従来法に比較 して精度良く定量できる有効な方法であると考えられた。

Table 6 Results of nitrazepam and diazepam from quantitative calculation

(1) Nitrazepam

\begin{tabular}{rccc}
\hline $\begin{array}{c}\text { Sample } \\
\text { No. }\end{array}$ & $\begin{array}{c}\text { Theoretixal value } \\
\mu \mathrm{g} / \mathrm{m} l(\mathrm{~A})\end{array}$ & $\begin{array}{c}\text { Calcylated value } \\
\mu \mathrm{g} / \mathrm{m} l(\mathrm{~B})\end{array}$ & $\begin{array}{c}\text { Ratio } \% \\
(\mathrm{~B} / \mathrm{A} \times 100)\end{array}$ \\
\hline 6 & 80.6 & 83.0 & 103.0 \\
7 & 161.2 & 164.8 & 102.2 \\
8 & 241.8 & 247.7 & 102.4 \\
9 & 282.1 & 283.0 & 100.3 \\
10 & 322.4 & 326.8 & 101.4
\end{tabular}

(2) Diazepam

\begin{tabular}{cccc}
\hline $\begin{array}{c}\text { Sample } \\
\text { No. }\end{array}$ & $\begin{array}{c}\text { Theoretical value } \\
\mu \mathrm{g} / \mathrm{m} l(\mathrm{~A})\end{array}$ & $\begin{array}{c}\text { Calculated value } \\
\mu \mathrm{g} / \mathrm{m} l(\mathrm{~B})\end{array}$ & $\begin{array}{c}\text { Ratio } \% \\
(\mathrm{~B} / \mathrm{A} \times 100)\end{array}$ \\
\hline 6 & 144.3 & 146.9 & 101.8 \\
7 & 112.2 & 113.5 & 101.1 \\
8 & 80.2 & 81.1 & 101.2 \\
9 & 64.1 & 65.0 & 101.4 \\
10 & 48.1 & 43.7 & 90.9
\end{tabular}




\section{4 結 論}

多変量解析法によるデータ処理は，測定から得られた複数の情 報（イオン強度）を同一の重みにして, 一つの数値に凝縮する。 したがって，ひとつひとつの情報の再現性が悪い場合でも，それ から生じる誤差を十分に吸収した結果が得られる。をた，複数の 主成分得点を補正して用いることにより，それらの情報の損失を 最小限にすることが可能となる。このことから，多変量解析法が GC/MS の定量分析に有用な方法であると考えられた。この方法 は，特定の情報のみを用いて定量を行ら従来法に比べ，より定量 精度の高い結果を導き出すことが明らかとなった。

\section{補 寈}

多变量解析法による定量分析法について, ニトラゼパムの未知 試料 No. 6 を例にして説明する。

まず，测定値を表 4 に示したような，多変量解析法で取り扱ら 数值に変換する方法として, 表 3 に示したフラグメントイオン拧 よび分子イオンのイオン強度と，それを中心として，その前後の 走查番号のイオン強度を測定する。この三つのイオン強度を合計 したものを求める。表 3 のカテゴリーNo. 1, 2, 3, ․, 11 の走査番 号のイオン強度は,

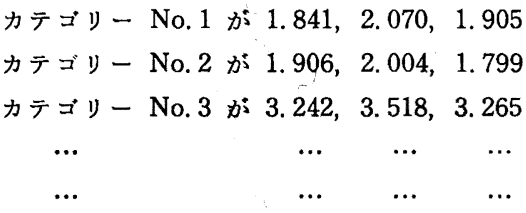

ただし，最初の数値が表 3 の $\mathrm{m} / \mathrm{z}$ の 1 つ前の走査番号のイオ ン強度, 2 番目の数值が表 3 の $\mathrm{m} / \mathrm{z}$ に相当する走查番号のイオ 強度, 3 番目の数值が表 3 の $\mathrm{m} / \mathrm{z}$ の一つ後の走查番号のイオ ン強度である。

それぞれのカテゴリーごとに合計したイオン強度，5.818， $5.709,10.025, \cdots, 13.577$ を求める。

次に, 表 3 に示したドトリアコンタンの 13 のカテゴリーにつ いても，同様の方法で各カテゴリーごとに合計したイオン強度を 求める。すなわち,

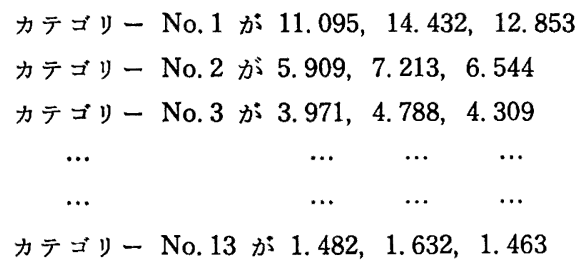

でそそれぞれのカテゴリーごとに合計したイオン強度は 38.380 , $19.676 ， 13.068 ， \cdots, 4.577$ となる。表 4 亿示した未知試料 No. 6 の数值は次のようにして求める。まず, (各カテゴリーの合計し たイオン強度 $) \times\left(1 / \mathrm{A}_{1}+1 / \mathrm{A}_{2}+1 / \mathrm{A}_{3}+\cdots+1 / \mathrm{A}_{13}\right)$ を計算する。 ここで, $A_{1}, A_{2}, A_{3}, \cdots A_{13}$ はドトリアコンタンの各カテゴリーの イオン強度の和である。この式から, 表 4 に示した未知試料 No. 6 のニトラゼパムの各カテゴリーの数值は

カテコリー No. 1 が

$5.818 \times(1 / 38.380+1 / 19.676+1 / 13.068+\cdots+1 / 4.577)$ $=14.497$
カテゴリー No. 2 が

$5.709 \times(1 / 38.380+1 / 19.676+1 / 13.068+\cdots+1 / 4.577)$

$$
=14.226
$$

カテゴリー No. 3 が

$10.025 \times(1 / 38.380+1 / 19.676+1 / 13.068+\cdots 1 / 4.577)$ $=24.982$

カテロ゙リー No. 11 が

13. $577 \times(1 / 38.380+1 / 19.676+1 / 13.068+\cdots+1 / 4.577)$ $=33.834$

となる。

ついで，未知試料 No. 6 の濃度决定（定量のために，表 4 の試 料 No. 1 から 5 (従来法での検量線に相当するもの) と, 未知試 料 No. 6 の計 6 行を取り出し（当然他の未知試料の定量の場合に は, 表 4 からそれに相当する行を取り出す), $6 \times 11$ 行列のデータ でクラスター分析を行ら。クラスター分析の結果から, 未知試料 が既知試料の濃度範囲内に存在するかどらかと, さらに未知試料 の大まかな濃度の推定（定性分析）を行った後, 主成分分析か ら，未知試料の定量を行ら。

定量方法は，まず主成分分析から各主成分と，その主成分に対 する固有值を計算し，計算に用いた全試料の主成分得点を求め る。すでに説明したように，定量分析には固有值 1.000 以上に 対する主成分得点のみを用いる。今回の計算例では, 固有値が 1.000 以上を示しているのは 1 つだけであるから，第 1 主成分得 点のみで定量することになる。通常, 従来法でる相対標準偏差が 大きいものの，何とか検量線が作成できるような場合には，本方 法では固有值 1.000 以上を示すのは第 1 主成分得点のみとなる。 表 4 の数值からの, 未知試料 No. 6 の計算結果は, 固有值が 10.992 と 0.007 となり，第 1 主成分得点のみで定量すれば良い ことがわかった。第 1 主成分得点は

試料 1 が 39.38

試料 2 か 44.41

試料 3 が 51.17

試料 4 が 57.94

試料 5 が 68.13

試料 6 かi 41.97

試料 6 が末知試料 No. 6

となる。未知試料 No. 6 の主成分得点が 41.97 たから，この主成 分得点を㣣んだ両端の主成分得点 39.38 と 44.41, さらにこの主 成分得点を示す試料 2,3 の濃度 (表 2 参照) から次のようにして 末知試料 No. 6 の濃度を求める。

$$
\begin{aligned}
& \log 39.38=40.3 \times a+b \\
& \log 44.41=120.9 \times a+b
\end{aligned}
$$

(1), (2) から

$$
a=1.491 \times 10^{-3} \quad b=3.613
$$

が得られる。この $a, b$ を用いて $\log 41.97=1.491 \times 10^{-3} \times C+3.613$ から未知試料 No. 6 の濃度 $C$ を求めると, $C=83.0 \mu \mathrm{g} / \mathrm{m} l$ が得ら れる。 


\title{
Determination of the Concentration of Nitrazepam and Diazepam with Many Fragment lons by Multivariate Analysis
}

\author{
Motoyasu SATo and Toshiyuki Mrtsul*
}

Criminal Scientific Laboratory Aichi Pref. Police H.Q.; 2-1-1, Sannomaru, Naka-ku, Nagoya-shi 460 Japan

After nitrazepam and diazepam were measured by gas chromatograph mass spectrometer (GC/MS), their quantitative analyses were carried out with the ion intensities of many fragment ions by multivariate analysis. Dotriacontane $\left(n-\mathrm{C}_{82} \mathrm{H}_{68}\right)$ was used as an internal standard. Their fragment ions of nitrazepam, diazepam and dotriacontane used for the quantitative calculation were subtracted with quantification IV. Cluster analysis, cluster analysis from deviation and principal component analysis were performed with the ion intensities of the subtracted fragment ions, and it was made certain which one of unknown samples among all was the closest to a given known sample. Furthermore, the concentrations of unknown samples were exactly determined with the principal component scores and eigen values obtained from principal component analysis. The calculated concentrations of nitrazepam and diazepam agreed well with the theoretical concentrations, and the quantitative analysis which has high preciseness was made possible. 